\title{
Seroprevalence of Mycoplasma bovis Infection in Dairy Cows in Ho Chi Minh, Vietnam
}

\author{
Dung Van Nguyen*, Chau Kim Thi Truong \\ Veterinary Diagnostic Laboratory, Sub. Department of Animal Healh, Ho Chi Minh City, Vietnam \\ Email: dungvanvn@gmail.com
}

Received 28 April 2015; accepted 23 May 2015; published 26 May 2015

Copyright $@ 2015$ by authors and Scientific Research Publishing Inc.

This work is licensed under the Creative Commons Attribution International License (CC BY). http://creativecommons.org/licenses/by/4.0/

(c) $\underset{\mathrm{EY}}{\mathrm{EY}}$ Open Access

\begin{abstract}
A cross-sectional study was carried out to investigate the seroprevalence of $M$. bovis. A total of 606 serum samples were randomly collected from dairy cows in Ho Chi Minh City, Vietnam. Commercial ELISA kit was used for detection of antibody to $M$. bovis. The results indicated that overall seroprevalence was $80.2 \%(486 / 606)$. There were no significant differences between regions or age categories $(\mathrm{P}>\mathbf{0 . 0 5})$. Degree of infection to $M$. bovis commonly distributed at positive degree 1 $(68.5 \%)$ and $2(24.1 \%)$. Seroprevalence at highest positive degree 4 were found in District 9 , District 12 and Thu Duc (6.7\%, 6.3\% and 1.6\%, respectively). This study is the first report of seroprevalence of $M$. bovis in Vietnam. The results suggested that $M$. bovis was spreading among dairy cow populations although degree of positivity was low. It should be considered as a high risk pathogen to dairy cows in Vietnam.
\end{abstract}

\section{Keywords}

Mycoplasma bovis, Diagnosis, ELISA, Dairy Cow, Prevalence

\section{Introduction}

Mycocplasma bovis (M. bovis) was the cause of mastitis, respiratory disease, arthritis and abortion in dairy cows [1]. In an infected dairy cows, mycoplamal mastitis affected more than $20 \%$ cows in all the stage of lactation and dry cows [2]. The mastitis in dairy cows leads to reduce milk production and quality of milk; especially, mycoplasmal submatitis is not easy to differentiate from other pathogens. Thus, control and prevention of $M$. bovis in dairy cows are very important to reduce damage from this bacterium. There are no quantitative data

${ }^{*}$ Corresponding author.

How to cite this paper: Van Nguyen, D. and Thi Truong, C.K. (2015) Seroprevalence of Mycoplasma bovis Infection in Dairy Cows in Ho Chi Minh, Vietnam. Open Journal of Veterinary Medicine, 5, 123-126.

http://dx.doi.org/10.4236/ojvm.2015.55016 
about prevalence of M. bovis in dairy cows in Vietnam now, especially, in Ho Chi Minh area where provide breed animals to neighbour provinces. It cannot have a proper measure for control of M. bovis in herd of dairy cows when basic data are lack. In this study, Enzyme-Linked Immuno Sorbent Assay (ELISA) was used for investigation of infection of M. bovis in Ho Chi Minh City, Vietnam.

\section{Materials and Methods}

A cross-sectional study was carried out in 2011 from all dairy cow breeding districts in Ho Chi Minh City (10 districts), Vietnam (Figure 1) This city is major cow milk production area in Vietnam (approximately 55\% total of dairy cow in Vietnam). Sample size was calculated with the program Win Episcope Version 2.0 using the mode "estimate percentages" for $60 \%$ seroprevalence, $5 \%$ error and $95 \%$ confidence, resulting in 606 animals from 79,800 cows. Blood samples were randomly collected from jugular vein of animal. The serum was collected by centrifugation at $3000 \mathrm{rpm}$ for $5 \mathrm{~min}$ and stored at $-20^{\circ} \mathrm{C}$ until analysis. Serum samples were tested by the indirect enzyme-linked immunosorbent assay (ELISA) using a commercially available kit (Mycoplasma bovis ELISA kit, Bio-X Diagnostics, Belgium). The testing was carried out according to the manufacturer's instructions with a photometer (Benchmard microplate reader, Bio Rad Laboratories, USA). The result is expressed as negative ( $\mathrm{S} / \mathrm{P}$ value $<9.74)$, as positive degree $1(9.74<\mathrm{S} / \mathrm{P}<39.88), 2$ (39.89 $<\mathrm{S} / \mathrm{P}<70.03), 3(70.04<\mathrm{S} / \mathrm{P}<100.18)$, $4(100.19<\mathrm{S} / \mathrm{P}<130.34)$ and $5(\mathrm{~S} / \mathrm{P}>130.35)[3]$.

Chi quare test was used for data analysis by Minitab software Version 13 (http://www.minitab.com).

\section{Results}

Antibodies against to M.bovis were found in 486 of 606 dairy cow $(80.2 \%)$ in all districts. The highest seroprevalence was in Tan Binh district (100\%) and lowest was in Hoc Mon district (72.9\%), other regions ranged from $75.0 \%$ to $88.9 \%$ (Table 1 ). However, there were not statistically significant differences among different geographical regions $(\mathrm{P}>0.05)$. The seroprevalence was commonly occurred at positive degree $1(68.5 \%)$ and $2(24.1 \%)$. Three districts with prevalence at positive degree 4 were found including District 9, District 12 and Thu Duc District. All districts had prevalence at positive degree from 1 to 2 (Table 1).

The highest seroprevalence was showed in animal group of over 4 years old and lowest was in group of $1-2$ years old. And other animal groups were similar in seroprevalence.

No relationship between the seroprevalence of different age could be found $(\mathrm{P}>0.05)$ (Table 2).

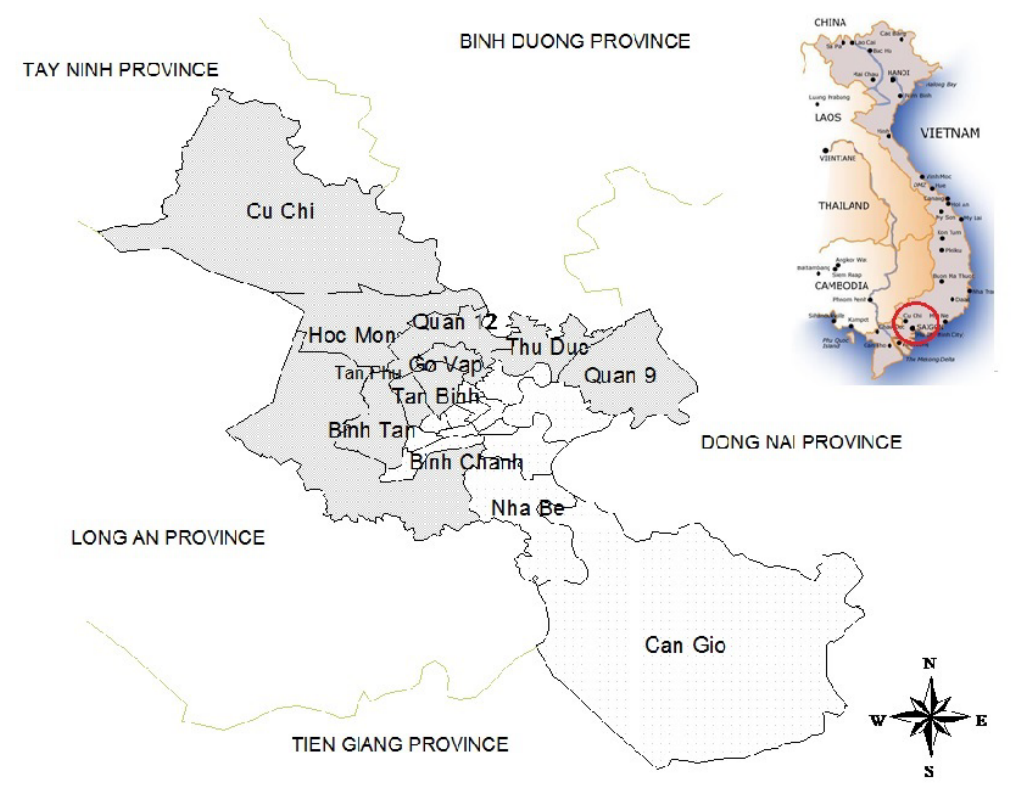

Figure 1. Map of sampling locations in Ho Chi Minh City, Vietnam. Districts with gray color were collected samples. 
Table 1. Seroprevalence of M. bovis infection by region and degree of positivity.

\begin{tabular}{ccccccccc}
\hline Area & $\begin{array}{c}\text { No. tested } \\
\text { sample }\end{array}$ & $\mathbf{( + )}^{*}$ & $\mathbf{( \% )}$ & \multicolumn{5}{c}{ Degree of positivity (\%) } \\
\hline District 9 & 20 & 15 & 75.0 & 40 & 40 & 13.3 & 6.7 & 0 \\
District 12 & 101 & 80 & 79.2 & 67.5 & 27.5 & 5 & 0 & $\mathbf{3}$ \\
Thu Duc & 20 & 16 & 80.0 & 43.8 & 31.3 & 18.8 & 6.3 & 0 \\
Binh Chanh & 45 & 40 & 88.9 & 77.5 & 20 & 2.5 & 0 & 0 \\
Binh Tan & 25 & 20 & 80.0 & 70 & 20 & 10 & 0 & 0 \\
Tan Phu & 15 & 13 & 86.7 & 76.9 & 15.4 & 7.7 & 0 & 0 \\
Tan Binh & 20 & 20 & 100.0 & 30 & 50 & 20 & 0 & 0 \\
Cu Chi & 170 & 141 & 82.9 & 70.9 & 22.0 & 7.1 & 0 & 0 \\
Hoc Mon & 170 & 124 & 72.9 & 74.2 & 20.2 & 4.0 & 1.6 & 0 \\
Go Vap & 20 & 17 & 85.0 & 76.5 & 23.5 & 0 & 0 & 0 \\
Total & $\mathbf{6 0 6}$ & $\mathbf{4 8 6}$ & 80.2 & $\mathbf{6 8 . 5}$ & $\mathbf{2 4 . 1}$ & $\mathbf{6 . 6}$ & $\mathbf{0 . 8}$ & $\mathbf{0}$ \\
\hline
\end{tabular}

$(+)^{*}:$ Number of positive samples.

Table 2. Seroprevalence of M. bovis infection in dairy cows by age.

\begin{tabular}{cccc}
\hline Age (year) & No. tested samples & No. positive samples & Prevalence (\%) \\
\hline $1-2$ & 98 & 71 & 72.4 \\
$3-4$ & 156 & 128 & 82.1 \\
$>4$ & 237 & 198 & 83.5 \\
No record & 115 & 89 & 77.4 \\
Total & $\mathbf{6 0 6}$ & 486 & 80.2 \\
\hline
\end{tabular}

\section{Discussion}

M. bovis is an important cause of bovine diseases such as mastitis, arthritis, and respiratory disease. M. bovis infections are found worldwide with various prevalence rates. The infection of M. bovis has been described throughout the world including most European and other countries [4]. Seroprevalence has been reported $7.69 \%$ in China [5], 66\% in Nigeria [6], and 76.6\% in Poland [7]. In this study, overall seroprevalence $(80.2 \%)$ was higher than that in other countries. The results showed that M. bovis was circulating in herd of dairy cows. The infection of antibody to M. bovis was commonly found at positive degree $1(68.5 \%)$ and $2(25.1 \%)$. This suggested that cows had previous exposures with this pathogen. The infection of M. bovis was detected in all dairy cow breeding regions and in all age of animals. It indicated that infection of $M$. bovis was quickly spreading among dairy cows in Vietnam. Infected cattle were observed to shed the agent through nasal discharge for some months to some years. Infected cows shed the agent in their milk represent a permanent reservoir [8]. Therefore, proper strategies and measures should be started to control and prevent M. bovis infection. Currently, antimicrobial therapy is applied, but often fails by antimicrobial resistance, leading to important economical losses [9]. Furthermore, this therapy might affect human health by using animal products with antibiotic residue. The vaccine measure should be considered. Commercial vaccine for $M$. bovis is available. However, it may be the best measure in uninfected animals. In infected populations, remove all cows with therapy-resistant mastitis and carry out proper hygiene. Furthermore, repeated monitoring of the herd is necessary.

\section{Acknowledgements}

This study support by Ho Chi Minh City Program for developing of dairy cows during the period 2011-2015 
(Grant No. 4320/QĐ-UBND). We would like thank to veterinarians from veterinary services in Ho Chi Minh for supporting of sample collection.

\section{References}

[1] Maunsell, F.P., Woolums, A.R., Francoz, D., Rosenbusch, R.F., Step, D.L., Wilson, D.J. and Janzen, E.D. (2011) Mycoplasma bovis Infections in Cattle. Journal of Veterinary Internal Medicine, 25, 772-783.

[2] Pfutzner, H. and Sachse, K. (1996) Mycoplasma bovis as an Agent of Mastitis, Pneumonia, Arthritis and Genital Disorders in Cattle. Revue Scientifique Technique (International Office of Epizootics), 15, 1477-1494.

[3] Bio-X Diagnostics (2010) Mycoplasma bovis ELISA Kit. Bio-X Diagnostics, Belgium. http://www.biox.com

[4] Nicholas, R.A. and Ayling, R.D. (2003) Mycoplasma bovis: Disease, Diagnosis, and Control. Research in veterinary science, 74, 105-112.

[5] Fu, J.H., Liu, Q.Y., Xu, M.J., Shi, D.S., He, X.H., Pan, Y., Guo, R.B., Gao, Q., Yi, S.X., Si, H.S. and Zhu, X.Q. (2013) Seroprevalence of Mycoplasma bovis Infection in Dairy Cows in Subtropical Southern China. African Journal of Biotechnology, 10, 11313-11316.

[6] Tambuwal, F.M., Stipkovits, L., Egwu, G.O., Junaidu, A.U., Abubakar, M.B. and Turaki, U.A. (2011) Enzyme-Linked Immunosorbent Assay (Elisa) Based Detection of Antibodiesto Mycoplasma bovis in Cattle Naturally Infected with Haemoparasites in Sokoto State, Nigeria. Current Research Journal of Biological Sciences, 3, 12-16.

[7] Dudek, K., Bednarek, D. and Szacawa, E. (2011) Evaluation of Immue Response in Seropositive Cattle for Mycoplasma bovis. Bulletin of the Veterinary Institute in Puławy, 55, 631-634.

[8] Pfutzner, F.L. (1990) Epizootiology of the Mycoplasma bovis Infection of Cattle. In: Stanek, G., Cassell, G.H., Tully, J.G. and Whitcomb, R.F., Eds., Recent Advances in Mycoplasmology, Gustav Fisher Verlag, Stuttgart, 394-399.

[9] Gautier-Bouchardon, A.V., Ferré, S.L., Le Grand, D., Paoli, A., Gay, E. and Poumarat, F. (2014) Overall Decrease in the Susceptibility of Mycoplasma bovis to Antimicrobials over the Past 30 Years in France. PLoS ONE, 9, e87672. http://dx.doi.org/10.1371/journal.pone.0087672 